\title{
Community Frames of Migration: The Path from Seaca to Spain
}

\author{
Alexandra Deliu ${ }^{12 *}$ \\ 1 University of Bucharest, Department of Sociology, 9 Schitu Măgureanu Blvd., Sector 5, 010181 - Bucharest, \\ Romania. \\ ${ }^{2}$ Romanian Academy, Research Institute for Quality of Life, 13 Calea 13 Septembrie, 050711 - Bucharest, Romania.
}

International migration Migration networks

Rural community

\section{ABSTRACT}

Transnational migration is a vast social phenomenon that has become a valid option for many Romanians since 1989. Romania is an emigration country and the favourite destinations of its citizens are Italy and Spain. This is the context in which I present my work, which focuses on the formation of transnational migration patterns from a village in the southern region of Romania. The data were generated during field research conducted in August 2012, and the empirical material consisted of field notes and interview transcripts corresponding to recorded conversations with local migrants, authority representatives and people without migration experience. In this particular community, two patterns of migration were identified, for which variables such as ethnicity (Roma/Romanian) and religious orientation (Orthodoxy/Adventism) appear to have explanatory power. My inquiry takes as its starting point the identification of this variety of migration patterns and concentrates on analysing them in the regional and national contexts based on the scholarly framework provided by network theory. Two major differences exist between them: the time frame of living and working abroad (clearly demarcated as three months, six months or indefinite) and the nature of the work environment (departures based on a work contract between the migrant and a company located at the destination and departures accompanied by uncertainty regarding workplace concerns upon arrival). Making sense of these life strategies and their local configurations are the objectives of this paper.

\footnotetext{
* Contact address: alexandradeliu@yahoo.com (A. Deliu)
} 


\section{Introduction}

This paper explores the existent avenues for international migration at community level, based on qualitative data obtained through field research carried in a contemporary rural community in Romania. As shown in studies, international migration from Romania to Spain relies heavily on social networks (Serban 2011). Further, in the examination of various migration routes, scholars have concluded that different forms of migration, oriented towards distinct ends (study/labour migration) is dependent on different types of social networks, either formal or informal (van Meeteren and Pereira 2013). In this analysis, I show that different types of individuals from the same community, following variables such as religious affiliation, ethnicity and gender, are part of and use as resource for migrating different networks. The paper starts by providing some theoretical perspectives and previous studies about networks and their importance in international migration and continues with a short description of the Romanian migration to Spain. In the intermediate sections of the paper, the theoretically informed expectations are stated and methodological details are discussed. Finally, the general situation of the community in relation to international migration is presented, as well as the patterns of migration from Seaca to Spain. The last part of the paper is the concluding one, in which the main empirical findings are reiterated.

\section{Networks in migration}

\section{General consideration}

Within the discussions on labour migration, a great deal of emphasis has been placed on explaining the mechanism through which individuals decide to migrate. From this core, multiple theoretical perspectives emerged, having as their basis different categories of explanatory factors: rationality as a human trait, individuals within the household, social actors and push-pull factors in the form of micro and macro theories (whether structural or 
individual). In this vast picture of migration theories, the perspective invested with explanatory power for this particular analysis is network theory. According to this theory, the social networks to which any person belongs account for his or her decisions regarding life choices and strategies - in this case, to either migrate or remain in the country/region of origin. As is the case regarding any particular version of theoretical explanations based on social networks, the implicit conceptual map of this perspective revolves around social capital as a distinct resource used by individuals to guide their actions, connecting them beyond the limits of their families (Portes 1998) and, though with lengthy variations, being inherent in their social lives.

Migrants are not autonomous individuals. The concept of migrant agency proposed by Castels (2007), which refers to the social connectedness of migrants as social beings and not merely as responding to economic triggers, takes into account the complex environment in which migration takes place-that is, the social situations in which individuals become migrants. In this context, network theory focuses on explaining the perpetuation-not the start-of migration. The existence of migration networks comprising ties between former, current and potential migrants reduces the costs and risks associated with migration and, in doing so, increases the probability of potential migrants becoming actual migrants (Massey et al. 1993, 448-449). This circular determination is the mechanism that accounts for the development of migration within a community/social establishment.

As Koser illustrates, technological development has contributed to the flow of information, enhancing people's awareness of opportunities and possibilities. Furthermore, networks have materialized and have contributed to the spread of migration, leading to the development of a migration industry (Koser 2007). Given the fact that, by relying on social networks, migrants find it easier to manage their transition and the initial adaptation to the conditions at the destination, networks are seen as contributing to the independence of migratory flows' (Light et al. 1989) by reducing the 
economic constraints that prohibit migration - that is, by curtailing the wide variety of costs associated with such a strategy.

For migration studies, informal networks based primarily on kinship and then extended towards weaker ties, are entities that mediate the incorporation of migrants; contrastingly, networks are shaped by their members and are not incremented entities, but vividly fluid ones ( $\mathrm{Hu}$ and Salazar 2005). Personal networks, based on mutual obligations, act as discriminatory criteria for migrants in relation to potential migrants by serving as a basis for the direction of help towards family members and friends (Fawcett 1989). As Şerban notes, there are two ways in which migrants can influence the behaviour of other members of the community: through information and through spending resources (whether time, money or help with the journey to the destination, finding a job, a place to live, etc.). While migrants inherently act as a source of information for the rest of the community, other types of help, involving the active investment of a certain type of resources, is a selective process that is dependent on the ties between the migrant and the potential migrants (Șerban 2011).

\section{Types of individuals, types of networks}

While the cost- and risk-reducing effect of social networks is undisputed, the way in which they work as social mechanisms at the destination is not at all linear and universal. Different status groups may utilize social networks differently and differences in individual characteristics may be translated into reliance on distinct social networks. Ethnicity, gender and religious affiliation, among others, have been analysed in migration studies in relation to the way migration experience is lived, the resorts for deciding to migrate, adaptation at the destination and so on.

For example, Van Meeteren and Pereira (2013) consider the case of Brazilian migration to Portugal and the Netherlands, and they suggest that different types of social networks are associated with different patterns of use on behalf of the individuals. Formal networks (institutions) are of particular relevance to people who choose to study abroad and are rather 
irrelevant to labour migration. Informal networks are precisely the opposite. Undocumented migrants' adaptation at the destination is critically influenced by the size and quality of their (most often, informal) social network.

Ethnic divides are associated with differences in resources used for migration. Slavkova (2008) discusses Gypsy migration linking Bulgaria and Spain and points out that, while the experience of migration contributes to shaping ethnic identity, ethnic differences - Gypsy-non-Gypsy - are maintained and, to a point, reproduced at the destination. The author shows that Gypsy migration from Bulgaria to Spain is convergent with the general trend of international mobility between the two countries but also emphasizes the importance of ethnic networks in perpetuating migration. Lubbers et al. (2007) point to the fact that ethnic self-identification is characteristic of migrants whose social network comprises mostly family members and migrants from the same community of origin, while more heterogeneous networks, in which the ties between individuals are more varied and more integrated at the destination, are associated with general rather than ethnicity-related identification. This is to say that the effect of migrant networks should be grasped as dynamic from a temporal perspective.

In dealing with migration and its importance in producing or catalyzing social change, Curran and Saguy (2001) bring forward matters such as gender and social networks. Drawing on Smith-Lovin and MacPherson's (1993) observation that women's networks differ from men's networks in that they reside on stronger social ties and, to a greater extent, kin ties, the authors provide analyses of how networks with distinct compositions impact the process of migration and highlight the dual influences between notions of gender identity and social networks, mediated through migration. Moreover, referring to the case of Mexico-U.S. migration and discussing gendered networks in this context, Davis and Winters (2001) show that male networks are more important that female networks for women's decision to migrate, whereas their choice of place of destination is 
more heavily influenced by the latter. Networks' influence on the lives of migrants is gender-based at the destination, as well: Hagan (1998) proves that social networks function differently for women than for men due to the different kinds of jobs that migrant women and men have at the destination. If men's jobs involve regular contact with both fellow migrants and people from the host society, women's social networks are structured differently because they are usually employed as 'intern' housekeepers and are thus isolated from society and confined to the social circle of the employer's family.

As far as the religious affiliation of individuals is concerned, studies show that religious networks and institutions are important actors in mobility across borders (Vertovec 2000; Fortuny-Loret de Mola 2002), mirroring religion's fundamental character in identity construction and selfdefinitions (Levitt and Jaworsky 2007). Particularly for the case of Romanian migration to Spain, religious affiliation a crucial aspect, with Adventists being among the pioneers, due to their tight social networks based on shared religious orientation (Șerban and Grigoraș 2000)

\section{From Romania to Spain}

With $19 \%$ of its working population living abroad (Bradatan and Sandu 2012), Romania is considered an emigration country. However, this was not always the case. For some 40 years, during the communist era, emigration was virtually nil. The demise of the communist regime impacted every interactional situation, from the interpersonal frame to the formal and institutional instances. Given this structural transformation and the new, though limited, permeability of borders, the beginning of the last decade of the twentieth century was the period in which the first work-related, individual, clandestine departures took place.

The history of Romanian migration has been dynamic and has consisted of various stages. Between 1996 and 2001, Spain became an important destination country for a significant number of Romanian 
migrants. Furthermore, it has since become an important destination for people living in Muntenia, Oltenia, Moldova and Crişana-Maramureş. Between 2002 and 2006 (prior to Romania becoming a European Union member state), Italy and Spain were by far the most important destination countries (Sandu 2005).

Today, Romanians and Moroccans constitute the largest immigrant group in both Spain and Italy (Bradatan and Sandu 2012). The Adventists were the pioneers of Romanian migration to Spain (Radu 2001), and in the early 1990s, they established the first Romanian communities in Spain. 'Daughter communities' have proliferated during the 2000s (Constantinescu 2005). Furthermore, the time frame from 2002 to 2004 was marked by the highest number of Romanians headed that way (Bradatan and Sandu 2012).

Migration to Spain relied heavily on the functioning of social networks, having primarily a familial base and spreading towards religious and community ties (Şerban and Grigoraș 2000). In the period spanning from 1990 to 2002, the informal networks related to the Romania-Spain migration were established and developed; however, their importance decreased after 2002 due to the supplemental freedom of international movement gained by Romanians, and they were partially replaced by formal networks (Bleahu 2004). This is not to say that there is a clear temporal delimitation in the existence of social networks as resources for migrants or that the role of these types of networks can be easily disentangled. The findings related to the influence of social networks on how migrants adapt, understand and use migration policies suggest that the dialectic between formal and informal networks and resources is complex. Analysing Romanian migration to Spain, Elrick and Ciobanu (2009) find that the development of migrants' networks is proportional to the effectiveness of their adaptation and that the functioning of networks of migration leads to the perpetuation of established patterns of migration. Thus, while helping individuals to effectively adapt to life abroad, social networks might also cause a certain degree of resistance to the changes imposed or opportunities brought about by migration policies. 
The existence of Romanian communities in Spain, characterized by the geographical proximity of immigrants, is a direct consequence of reliance on the help of established migrants when it comes to finding a job, a place to live or, generally speaking, when it comes to assistance towards and at the destination (Mihai 2009). Nevertheless, while 25\% of Romanians clustered in the Madrid region, they constitute the most widespread group in Spain (Martinez 2011). For men, the most important sector of employment is construction and, for women, this is housekeeping (domestic), especially in urban areas such as Madrid. In addition to these two sectors, agriculture is also important; however, there is a gender-blind economic niche with high concentrations of Romanians in Almeria (Șerban and Grigoraș 2000).

\section{Expectations}

The focus of the present inquiry is to describe and analyse migration from a Romanian village as a network-based phenomenon. Furthermore, because working abroad is not a homogenous phenomenon but rather fosters numerous ways of being a migrant, I expected to find multiple social networks corresponding to different patterns of migration within the community. It is hypothesized that different personal characteristics and attributes lead to individuals relying on different networks, as resources that fuel their migration experiences.

In the analysis, there are two basic starting points for discussing these patterns-either having the individual characteristics as the reference or relying on the specificities of the migration event. Here, my choice is the latter1:

\footnotetext{
1 A similar model was proposed by Troc (2012), who introduced three categories: Orthodox migration, Roma's migration and Adventist migration.
} 
Table 1: Patterns of migration from Seaca to Spain

\begin{tabular}{|l|l|l|l|}
\hline \multirow{2}{*}{$\begin{array}{l}\text { Individual } \\
\text { characteristics }\end{array}$} & $\begin{array}{l}\text { Contract-based } \\
\text { migration }\end{array}$ & \multicolumn{2}{|l|}{ Temporally undetermined, not contract-bound migration } \\
\cline { 3 - 4 } & Jobs in agriculture & Jobs in construction/housekeeping \\
\hline Gender & Women & $\begin{array}{l}\text { Both men and } \\
\text { women in the same } \\
\text { economic sector }\end{array}$ & $\begin{array}{l}\text { Gendered pattern of employment: } \\
\text { men in construction and women in } \\
\text { housekeeping }\end{array}$ \\
\hline $\begin{array}{l}\text { Religious } \\
\text { affiliation }\end{array}$ & Orthodox & Orthodox & Adventist \\
\hline Ethnicity & Romanian & Roma & Romanian \\
\hline
\end{tabular}

First, in keeping with the typology proposed by Șerban (2011), a major area of distinction is to be found on the formal/informal axis in regard to the expected jobs at the destination. One can either select the option of temporary work contracts in agriculture for periods of three, four, six or nine months, or one can opt for the possibility of leaving for Spain without any formal contract and, thus, no guarantee of securing a job immediately. As Table 1 suggests, while contract-bound departures are mostly specific to Romanian orthodox females, men who are either Roma or Romanian, orthodox or Adventist also migrate following informal channels of securing a job.

Another area in which differences arise is the economic sector in which migrants engage at the destination. While Romanians, be they orthodox or Adventist, enter a gendered job market (Bradatan and Sandu 2012), with men working in construction and women in housekeeping, Roma men and women mostly work in agriculture.

As such, it was expected that the existence of three distinct networks relevant to migration from Seaca to Spain would be traced in the empirical data.

\section{Data and methodology}

The analysis is based on 19 interviews conducted as a part of a comprehensive body of research carried out by the Soros Foundation in August 2012. The study focused on the social effects of migration on sending 
communities. This period was chosen because of the high probability of finding migrants in their community of origin: Seaca, Teleorman county and Romania. This particular village was chosen on two grounds-the prevalence of migration that characterizes it and the accessibility allowed by social connections between the researchers and some members of the community. The empirical data used consist of transcripts of the 19 interviews - 1 or 2 respondents each - and research notes taken by the two interviewers. Respondents' pool consisted of 7 men and 15 women; 17 Romanians and 5 Roma and 2 Adventists. The two interviews conducted with Adventists were supplemented by the participation to their weekly Saturday gathering, which resulted in vast research notes.

Having the interview as the primary research method and the initial research as the context, the data are dealt with by acknowledging a series of aspects. The first concerns the difference between the original purpose of this research and the theoretical and analytical framework of this study. The broad inquiry into the consequences of migration as they are to be seen within the community was an opportunity to locate the general lines of migration and a platform from which various distinct further paths could emerge. At the same time, it did not allow for an in-depth exploration of specific sub-topics. Contrastingly, this lack of focus, translated methodologically into loose conversation guides, allowed the respondents to better control the situation and to present, in the interviews, aspects strictly related to their own system of relevance and their understanding of what was important, crucial or significant about their experience.

Further on, the specific method through which data were generated has its own advantages and limitations with regard to the assertions that can be made and the hypotheses or theoretically shaped expectations that can be tested or engaged with. For example, instead of following leads regarding how many migrants can be found in the community and integrating the information into larger frameworks and regional/national patterns, the existence of types, alternative possibilities and materializations can be shown here. This is compatible with the scope of this study, which is namely 
to discuss the existence of various patterns of migration and to analytically integrate these into a more encompassing social frame.

\section{Community frames of migration}

Seaca commune, comprising two villages - Seaca and Năvodari - is located in the county of Teleorman in the Danube Meadow. It is separated from the closest city, Turnu Măgurele, by a distance of 15 kilometres and is 40 kilometres from the Alexandria county residence. On a daily basis-once in the morning and once late in the afternoon-bus rides connect Seaca and Turnu Măgurele. Seaca commune has been depicted by some as 'a poor commune in a poor county in a poor region'. In Seaca, one can find a few local businesses (five general stores, one bar and one discotheque) along the main road. There are no banks and, generally, no visible sign of economic connections to the 'outside' world. The following are, nonetheless, to be found: one post office; one elementary school; one public library; one kindergarten; one pharmacy; one medical facility with one doctor and one pharmacy; and two religious institutions-an orthodox church and an Adventist house of prayer.

As an administrative and territorial unit, Seaca has 2,538 inhabitants and 1,086 households. The research was concentrated mainly in the village Seaca, where, according to the information provided by the local administration, from an ethnic perspective, the population consists of $50 \%$ Romanians and 50\% Roma, while from a religious perspective, $70 \%$ are Orthodox and $30 \%$ are Adventists. ${ }^{2}$ The information revealed by the mayor suggests that the annual number of births (5-6) is significantly lower than the number of deaths (40-50). This demographic trend, along with the high number of people who adopt migration as a life strategy, has a major impact on the way in which institutions function in the community, and the specific

\footnotetext{
2 These numbers are not convergent with census data for Roma and Adventists in the commune: $5 \%$ and, respectively, $3 \%$ (data available at http://www.insse.ro). A possible explanation is based on the fact that the census took place in November, a month when migrants are usually abroad.
} 
sector in which this impact is likely to be most significant is formal education. In recent years, the configuration of formal education in the commune has shifted from having a school in each village (Seaca and Năvodari) to having only one school, located in Seaca that serves both villages. Furthermore, with regard to primary education, classes are merged for the first and third grades, as well as for the second and fourth grades, due to the small number of children enrolled in these classes.

In this community, the history of migration began in the period following the 1989 change of political regime. The first work-related international departures occurred in the 1990s. Today, as far as destinations and routes of migration are concerned, Spain is by far the most popular country. In the beginning, Germany was also a leading option for migrants and potential migrants. As the mayor recalls, the first individuals, Orthodox Roma, became migrants in 1996. Chronologically, the first destination, Germany, was replaced by Spain between 1997 and 1998 when migrants returned from Germany and began exploring other destinations. In 2012, approximately 500 people with the right to vote lived abroad, half of whom belong to the Roma ethnic group.

There are essentially two distinct ways of 'doing migration' in the community - based on pre-established work contracts in agriculture or as 'independent' departures without any formal arrangements regarding a job at the destination. While people with work contracts usually travel back and forth between Romania and Spain or Germany, long-term, unarranged work migration is primarily directed towards Spain.

The years 2001 and 2002 marked an important moment in the development of migration in the community. As various respondents mentioned, the fact that in 2002 a new relationship between Romania and the Schengen space was established, which meant there were no visa requirements for Romanian citizens travelling abroad in countries that were members of the Schengen convention, made the whole process of leaving abroad for work easier. This relaxation of laws governing international mobility, combined with the fact that, after 1989, the Romanian economy 
was in decline, created the context for this newly available life strategy. The initial necessity of obtaining a visa was usually fulfilled by acquiring one from specialized brokers on the black market. The price for such a service was approximately 1,000 German marks; as such, being able to circulate more easily within the Schengen space cut the financial costs associated with migration and contributed to a reduction of the uncertainty characteristic of the social trajectory of undocumented migrants.

Migration is constructed as an economically motivated decision - a solution for those who are either unsatisfied with their economic situation or hardly managing to secure their daily necessities in the country of origin. The combined scarcity of jobs and the perceived lack of opportunities for the future are the recurring themes linked to labour migration. Given the extent to which this phenomenon is known within the community due to the large number of people who choose to experience it, either as an 'on one's own' informal path or in its formalized variant-that is, accompanied by work contracts - it is only natural to find established narratives on this topic. Who leaves? Who stays behind? What are the options in the native country? Is returning home an option, and, if it is, when is the best time to do so? These are all questions that can be easily traced in the literature on migration, and they are, at the same time, part of the day-to-day struggles that people face. Additionally, they are often thrust into difficult, life-altering decisionmaking processes.

With regard to the individual or community assessments of migration, a very important aspect is its visible effects (Șerban 2011, 192). In other words, finding clues to how the migrants are coping abroad and whether or not they are successful is closely linked to the general evaluations of this new, innovative life strategy. Moreover, these evaluations enter the equation regarding the spread of migration beyond the very bold decision of the very few first migrants. Thus, highlighting the visibility of the effects of migration at the community level provides a clear view of both the narratives on migration (in which they are embedded) and the existing patterns of migration. 
In Seaca, the most notable sign or result of migration is the oversized houses that one can find while passing through the village via its main road (national road number 51A-DN 51A). What is interesting is that the spatial location of this type of house is linked to the presence of both the main road and the commune's civic/social centre. All the respondents point out the story behind this clustering: 'The gypsies' left to work abroad; they did what they did over there, came back with large sums of money and then purchased old houses in central locations. These houses were bought from Romanians who, being offered enormous sums of money for their houses and the adjacent land, agreed to sell. The sellers, in return, used only a small part of the money to buy other houses in peripheral parts of the village and kept the rest for themselves. These transactions are discursively shaped as somehow out of the ordinary due to the large amount of money offered for the houses-amounts that far exceeded regular market price. In these conditions, the initial owners, repeatedly referred to as 'Romanians', found it extremely efficient to sell and to relocate while, at the same time, significantly improving their financial situation. To grasp the serious impact of these transactions on the housing market, one has to keep in mind that jobs are rather scarce in the commune; most people work in agriculture, which has low returns as a means of subsistence.

As previously mentioned, the ethnic configuration of the commune comprises two groups of approximately the same size-Romanians and Roma. In this context, the change in landscape detailed above becomes fundamental for a deep distinction, revealed throughout the interviews with Romanians, between these groups. On the one hand are the gypsies, who are seen as more successful migrants who made a great deal of money abroad and chose to spend it extravagantly, such as by purchasing houses that were too large for their needs - that is, houses with two or three levels. On the other hand are the Romanians, who just went abroad to find the resources for coping with life's necessities. If, in the case of the Romanians, emphasis is placed on the grim economic situation of the country and the region as a whole, with regard to gypsies, what is most prominent in the majority of 
discourses is their pattern of spending, at the origin, the money earned at the destination. Nevertheless, when examined objectively and based on traceable terms, the economic situation that Roma people had to face after 1989 has probably been more serious than that faced by the Romanians. While many individuals from Seaca had jobs in Turnu Măgurele or even Alexandria, especially in the industrial sector, Roma people usually held unstable jobs as day labourers in agriculture and/or worked in Romanian households, thus making them extremely vulnerable to economic and social change. This is a strong argument for my claim that, inside the community, even though there are no conflicts between members of the two ethnic groups, there is a strong sense of belonging and ethnic identification on the one hand and, on the other, a strong perception of the others as being different in ethnic terms. Consequently, an important differentiation regarding what concerns the patterns of migration is based upon ethnicity as an explanatory variable.

Roma, compared to Romanians, are perceived as being successful, doing 'God knows what' and periodically coming back to invest in their newly built houses. An interesting detail is that, even though everyone agrees that the gypsies from the village were not thieves but rather hardworking and honest people back in the days when they worked in local agriculture, a picture with much broader possibilities is painted for their lives and their work abroad. This is particularly the case because of Roma and Romanians' different methods of spending the money earned abroad. While, as previously mentioned, the former invest heavily in housing, the latter's types of expenses are transposed into far less visible indicators, especially in covering the everyday necessities of a family, such as school, health and work-related investments.

Within the community, migration is seen as a solution for improving the economic status of individuals and households. People argue against what they call 'the common opinion that life abroad is easy and you can have everything without lifting a finger'. Instead, they emphasize that the difference between Romania and Spain, as the main destination, is the fact 
that over there, unlike what happens at home, hard work is rewarded as it should be and, even though you have to 'work like a slave' sometimes, you get a fair salary for what you do. Often, Spain becomes the equivalent of normality and the place where things are 'as they should be'. This is most often the case with regard to the way in which institutions work, the rights of the citizens and when comparing the Romanian health system with the Spanish one. Also, from a social and cultural perspective, the positive effect of migration on individuals has also been a common theme in the interviews and informal undocumented conversations with different people in the community. Through migration, one gets to explore new values, behaviours and ways of being, and all these enrich the migrants' horizons and the repertoire of practices in everyday life situations.

\section{Patterns and networks in international work migration}

In the following section, methods of migration for work are described in relation to the corresponding social networks whose existence is empirically documented.

\section{Migration using informal channels/resources.}

This general migration pattern comprises individuals who choose to migrate to find a job abroad without using any formal means or resources, such as bilateral agreements that facilitate circulatory work migration.

A common theme in the discourses of both Roma and Romanian respondents was the necessity of building a reputation for being hardworking, honest and responsible in the eyes of employers:

R: '... I, as a Romanian, if the Spaniard knew me and I was telling him Look, you have an opening here. Do you want to hire a Romanian? And then, because of my qualities... they thought that all the Romanians were just as good (as myself).'

I: 'Through recommendation...' 
R: 'And then, I recommended him: He is a good driver, a good mechanic... And the Spaniard would hire him (the Romanian). And then, I carried them all. 7 or 8 people I think, plus others who... really, I used to lie and say He is mi primo, my cousin... I brought them into the world.' (Former long term migrant, Orthodox Romanian)

For a stranger in a new culture who is confronted with a new set of social practices, work becomes the central component of his or her life. It is the means to the goal that motivated the act of migration itself - to gather sufficient money to be able to face life at home. It is for this reason that being seen as a good asset represented the gateway to securing what the migrants came for in the first place. Once established, this portrait is characteristic not only of the named Romanian immigrant, but of the whole immigrant group. Based on this line of thought, being a successful migrant not only influences the behaviour of potential migrants in the home community, making them more prone to migration, but also opens up possibilities for them at the destination by contributing to the development of positive ethnic-based stereotypes.

One distinct economic strategy that is characteristic of both groups is that of the documented work/paid unemployment cycles. These are easiest to understand in regard to agriculture, where they are linked to crops and harvests. This strategy means working for a while-usually eight to nine months-and then receiving unemployment benefits for the remaining period of the year. People who leave for work on the basis of a formal contract, signed at the origin, for periods of at least nine months can also receive unemployment benefits. The rule is that there has to be a minimum of 272 days of work in order to qualify for this social measure. These amounts of money vary from 400 to 1,000 Euros, depending on the length of the documented work period and the value of the wages. Contrastingly, the average net wage in Romania in 2012 was approximately 350 Euros per month. It is a selective strategy because it requires the migrant to be documented and to have a work permit; however, for the migrant respondents, it constitutes major proof of the fact that they are seen and treated as 'real citizens' by the Spanish state. 


\section{1a) Romanian migrants.}

In the case of Romanian migrants, the decision to migrate appears to be closely linked to the existence of a relative or an acquaintance living abroad. There is a close connection between the departures of Adventist and orthodox Romanians, especially given the fact that, once established in Spain, their occupations are similar. Chronologically, the first Romanian migrants were Adventists. They settled around Madrid, especially in Coslada, with men working in construction and women working in the domestic sector. Migration to Spain implied the acquisition of a visa, obtained primarily through informal channels-that is, by turning to specialized middlemen who were not locals. In the interviews, two such middlemen were indicated, one of whom was from Bistrița-Năsăud and the other from Bucharest. Once established there after 1996, they found it impossible to return home for holidays because of their lack of legal documents; coming home was too expensive an alternative because returning to Spain required another visa, which, in turn, involved spending between 1,000 German marks and 2,000 American dollars in addition to travel costs. Usually, the first ones to leave were men, who, after spending time settling down and finding work and a place to live, were followed by their wives and children. This gendered pattern is documented in the analyses of Romanian migration to Spain (Martinez 2011; Sandu 2005) and can be easily explained in terms of risks associated with migration and the traditional male role of protector of the family. Another complementary explanation is represented by the fact that while men had various opportunities to obtain a job in a variety of subdomains initially connected with construction, the economic niche for women was restricted to the domestic sector.

Even though the first Romanians to leave were Adventists, their migration network soon came to include Orthodox people from the community. One respondent explains:

'They used to borrow money here in order to be able to leave, and one, two, three Adventist families from Seaca left and they dragged each 
other. At first, they left alone, afterwards they took their children with them, and, first of all, they started to leave for Spain in 98-99, 2000 2001. With them, Orthodox Romanians left as well.' (Former primary school teacher, woman in her '50s with no migration experience)

Thus, it can be stated that religious orientation did not act as a discriminator or selective factor regarding Romanians' migration, despite the fact that this specific pattern, without previous work contracts, is rather more characteristic of Adventist than Orthodox Romanians. In other words, knowing a settled migrant or 'having someone abroad' was a connection that spanned religious differences. At the same time, ethnicity seems to be an important variable, with this specific network only comprising Romanians.

\section{1b) Roma migrants.}

Another variation of this pattern of migration is specific to Roma people. While Romanians were able to secure jobs in construction and housekeeping and settled in urban areas around Madrid, Roma migrants sought work within the agricultural sector and settled in areas such as Almeria or Huelva. From what the respondents suggested, while Roma worked exclusively in agriculture, this economic sector was not approached by any Romanian migrant from the community. Here too, men were the first to become migrants (the father-son pair was common), followed by the female family members and the children. Without the involvement of any religious aspect, Roma's migration from Seaca is also based on the existence of social networks. For Roma, Spain was not the first destination. Previously, countries such as Serbia and Germany were common destinations in the period from 1991 to 1997. In regard to these flows of migrants, the key element was the information about job opportunities; as one respondent explained, they would go wherever the rumours directed.

Today, most migrants are documented and lead a secure, risk-free life in Spain. They work amongst their fellow Romanians, with whom they interact most often in the parking lots outside the fields while waiting for 
their employers to arrive. They usually remain employed to the same firm for years because, as they say, they prove their value to their employers. They also explain that everyone knows where in the area other Romanians work and for which employer. The fact that they are not paid by the hour, but based on the quantity of fruits or vegetables they manage to gather, increases their sense of responsibility; they are directly responsible for their own wages without the mediation of any entity who decides whether or not they have done a good job.

From a social perspective, the respondents associate migration with the transition from 'a gypsy in Romania' to 'a serious worker in Spain', because abroad they cease to be Roma - they are simply a Romanian person in search of a normal life. ${ }^{3}$ Moreover, this search is almost always successful.

\section{Contract-based circulatory migration.}

Being a documented migrant with an official work contract for a limited period seems to be the most selective category of the three presented in this study. For this pattern, gender, religion and ethnicity are relevant variables. These migrants are Romanian orthodox women who are usually married with children. The route towards this type of departure involves participating in a preselection organized by a specialized firm that is most often located in Slatina, the residence of neighbouring Olt County, where you have to document your skills as an agricultural worker and the state of your health. The preselection is also the moment when you are made aware that you have to be able to work in harsh conditions and must be prepared for the worst. The Spanish employer provides accommodation in special facilities (dorms) near the fields to be harvested, and transportation costs are evenly split between the employer and the employee. Comments such as 'All the girls were talking about it, and so I went there myself' and 'I had someone who told me about the preselection and took care of the required paperwork' were supplied as answers to how the respondents found out

\footnotetext{
3 This empirical finding is an example of how, through migration, social categories and their meanings are reshaped and adjusted (Tilly 1991).
} 
about these opportunities or what drove them to apply.

The working environment at the destination is feminized and exclusively Romanian, apart from the employers and employees operating the machinery. This pattern of migration has two outcomes: the creation of Romanian teams of agricultural workers and finite periods of economic activity for the migrants. The respondents mentioned that they worked for the same firm and in the same team for extended periods of time or, alternatively, every time they left. The geographical isolation from Spanish localities and the sociocultural clustering of migrants make returning to Romania yet another necessity in addition to leaving the family at home. In the case of these migrants, children are named as the main reason for migrating; the aim is to provide them with a better future, proper schooling and, overall, better chances in life. However, these advantages are balanced, as the respondents point out, by the adverse effects of the relationships between children and their mothers and between spouses who have to overcome the distance. As one respondent mentioned, the first time is the worst: children end up in tears, mothers feel guilty and a gap emerges between them. Nevertheless, as the years go by, children grow up, the cycle of departure-return repeats itself and, finally, it all becomes the normal way of life for the family.

\section{Conclusions}

With more than 20 years of migration history to various destinations, Seaca is an emigration community in which working abroad is regarded as the only viable economic plan. Situated in a region in which economics and politics are entwined in the public discourse, creating an incommensurable gap between lay people and local authorities, the community's economic and occupational characteristics were partly shaped by the fall of the communist regime and the long transition that followed. In the recent past, many people held jobs in Turnu Măgurele and Alexandria; today, agriculture is the main sector in which work is concentrated. Elderly people 
have small pensions as a result of them working in the local CAP, the stateowned unit of agricultural production, based on the activity of working peasants, while for the majority of the working population, cultivating the land is the means of subsistence.

Migration constitutes a non-permanent strategy of acquiring resources and increasing one's economic status. Independent of the individual choice regarding what concerns the specific method of 'doing migration' - either using formal or informal channels - returning home is constructed, based on the interactions with the researchers, as a temporally volatile certainty. 'Home' means familiarity and a strange type of comfort; while normality is found abroad, along with decent standards of living, the origin is the place where one can always get along one way or the other. As one respondent mentions, 'out there, if you don't have a job, you're ruined, you practically starve to death; whereas, at home, you can always turn to your own, small vegetable garden or to the few backyard poultry you might have'. Abroad, the symbolic importance and value of having a job is deepened by the perspective of being unemployed and undocumented among foreigners and by the fact that working, either legally or without formal contracts, is, in fact, the sole objective - an objective that leads migrants to accomplish the goal of earning sufficient money to be able to lead an economically secure life at home.

In the community, there are several ways of 'doing migration'. To analyse these, it is necessary to acknowledge the importance of a set of individual characteristics. Gender, religion and ethnicity form an intersectional field related to working and living abroad. Romanian orthodox women usually leave on the basis of a pre-established contract and work exclusively in agriculture; Roma women follow their spouses and work by their sides in agriculture. However, unlike the circulatory migration of Romanian women, Roma women find a job once they become established at the destination. Adventist women (as well as the very few orthodox women who choose the informal path of migrating) mainly work as housekeepers or caregivers. Contrastingly, Roma men work in agriculture, 
while Romanians, whether orthodox or Adventist, work in construction. However, irrespective of the migratory routes, networks are present in every account: migrants either found out about preselection from friends and acquaintances who urged them to participate, or they went abroad to a relative or friend who had already settled there.

Migration has its most visible effects in the case of Roma migrants, who engaged in a process of territorial displacement at the origin by purchasing old Romanian houses and the adjacent land situated in the centre of the commune on the main road. They then demolished them and constructed their own multilevel establishments, which commonly consisted of a ground floor plus two additional levels. For Romanians, migration proves to be rather subsistence oriented, with a pattern of spending remittances on schooling and covering other routine expenses.

The analysis shows that, in this particular community, multiple social networks in which migration flourishes exist relatively independent of each other. Women leaving for work on a pre-established basis gather their information from other women who have already experienced it or have first-hand knowledge of its requirements and rewards. A whole other type of experience is presented by indefinite-term migrants, whose departure is not dependent on formal work contracts. Roma and Romanians who choose this path are also differentiated on various points, from their religious profile and the gender distribution among migrants to the jobs they hold at the destination. Their decision to migrate is based on information gathered from previous migrants, and their actual departure depends on the support of people located at both ends of the origin/destination continuum. At the same time, it is a solid empirical finding that the network that supports the migration of Roma is distinct from the Adventist network on which the migration of Romanians (Adventists and Orthodox men) is based.

More empirical research and more focused data are required to better understand the configuration of these patterns, their possible continuation and the differences in the ways in which they shape migrants' expectations, future plans and social evaluations. Furthermore, an inquiry into the 
interactional positioning of various migrants with distinct migration paths would shed additional light on the significance of this phenomenon for individuals and the way in which it is dealt with discursively at the community level.

\section{Acknowledgements}

This article is made and published under the aegis of the Research Institute for Quality of Life, Romanian Academy as a part of a programme co-funded by the European Union within the Operational Sectorial Programme for Human Resources Development through the project for Pluri and interdisciplinary in doctoral and post-doctoral programmes. Project Code: POSDRU/159/1.5/S/141086.

The article is also supported by the CNCS-UEFICDI grant PN-II-ID-PCE2011-3-0210.

\section{References:}

Bleahu, Ana. 2004. Romanian migration to Spain. Motivations, networks and strategies. Public Policy Centre, accessed February 28, 2015, http://pdc.ceu.hu/archive/00003393/

Bradatan, Cristina E., and Dumitru Sandu. 2012. “Before Crisis: Gender and Economic Outcomes of the Two Largest Immigrant Communities in Spain: Gender and Economic Outcomes." International Migration Review 46(1): 221-243.

Castles, Stephen. 2007. "The Factors that Make and Unmake Migration Policies." In Rethinking Migration. New Theoretical and Empirical Perspectives, edited by Alejandro Portes and Josh De Wind, 29-61. New York: Berghahn Books.

Constantinescu, Monica. 2005. "The importance of reference system in international migration: the duality origin country - destination country or system perspective?" In European Integration from East to East: Civil Society and Ethnic Minorities in a Changing World, edited by Horațiu Rusu and Bogdan Voicu, 31-46. Sibiu: Psihomedia.

Curran, Sara R. and Abigail C. Saguy. 2001. "Migration and Cultural Change: A Role for Gender and Social Networks?" Journal of International Women's Studies 2(3): 54-77. 
Davis, Benjamin and Paul Winters. 2001. "Gender, Networks and Mexico-US Migration." The Journal of Development Studies 32(2): 1-26.

Elrick, Tim, and Oana Ciobanu. 2009. "Migration Networks and Policy Impacts: Insights from Romanian-Spanish Migrations." Global Networks 9(1): 100-116.

Fawcett, James T. 1989. "Networks, Linkages, and Migration Systems." International Migration Review 23(3): 671-680.

Fortuny-Loret de Mola, Patricia. 2002. "The Santa Cena of the Luz Del Mundo Church: A Case of Contemporary Transnationalism." In Religion across Borders: Transnational Immigrant Networks, edited by Helen R. Ebaugh and Janet Saltzman Chafetz, 15-50. Walnut Creek: Alta Mira Press.

Hagan, Jacqueline Maria. 1998. "Social Networks, Gender, and Immigrant Incorporation: Resources and Constraints." American Sociological Review 63(1): 55-67.

$\mathrm{Hu}$, Xiaojiang and Miguel A. Salazar. 2005. “Dynamic Change of Migrant Networks: How migrant networks change under changing environment." Paper presented at Summer Institute on International Migration. Irvine: UC. Available at http://www.researchgate.net/ profile/Xiaojiang_Hu/publications/.

Koser, Khalid. 2007. International Migration: A Very Short Introduction. Very Short Introductions 157. Oxford: Oxford University Press.

Levitt, Peggy, and B. Nadya Jaworsky. 2007. “Transnational Migration Studies: Past Developments and Future Trends." Annual Review of Sociology 33(1): 129-56.

Light, Ivan, Parminder Bhachu, and Stavros Karageorgis. 1989. "Migration Networks and Immigrant Entrepreneurship." In California Immigrants in World Perspective: The Conference Papers, April 1990, Institute for Social Science Research. Los Angeles: UC. Available at http://escholarship.org/uc/item/50g990sk

Lubbers, Miranda Jessica, Jose Luis Molina, and Christopher McCarthy. 2007. "Personal Networks and Ethnic Identifications: The Case of Migrants in Spain." International Sociology 22(6): 721-741.

Massey, Douglas S., Joaquin Arango, Graeme Hugo, Ali Kouaouci, Adela Pellegrino, and Edward J. Taylor. 1993. "Theories of International Migration: A Review and Appraisal." Population and Development Review 19(3): 431-466.

Martinez, Rafael Viruela. 2011. “The Romanian Migrants in Spain. An Exceptional Migratory Flow." International Review of Social Research 1(1): 31-59. 
Van Meeteren, Masja, and Sonia Pereira. 2013. “The differential role of social networks. Strategies and routes in Brazilian migration to Portugal and the Netherlands." International Migration Institute Working Papers Series, 66. Oxford: University of Oxford.

Mihai, Ioana Alexandra. 2009. "Capitalul social al migranților." In Comunități Românești în Spania, edited by Dumitru Sandu, 82-92. București: Fundația Soros România.

Portes, Alejandro. 1998. "Social Capital: Its Origins and Applications in Modern Sociology." Annual Review of Sociology 24(1): 1-24.

Radu, Cosmin. 2001. "De la Crângeni-Teleorman spre Spania: antreprenoriat, adventism și migrație circulatorie." Sociologie Românească (1-4): 215-231.

Sandu, Dumitru. 2005. Locuirea temporară în străinătate. Migrația economică a românilor: 1990-2006. București: Fundația pentru o Societate Deschisă.

Slavkova, Magdalena. 2008. “Being Gypsy in Europe. The Case of Bulgarian Roma Workers in Spain." Balkanologie 11(1-2): 2-16.

Smith-Lovin, Lynne and J. M. MacPherson. 1993. "You Are Who You Know: A Network Approach to Gender." In Theory on Gender, Feminism on Theory, edited by Paula England, 223-254. New York: Aldine de Gruyter.

Șerban, Monica and Vlad Grigoraș. 2000. “Dogenii din Teleorman în țară și în străinătate. Un studiu asupra migrației circulatorii în Spania." Sociologie Românească 2: 30-54.

Șerban, Monica. 2011. Dinamica migrației internaționale: un exercițiu asupra migrației românești în Spania. Iași: Lumen.

Tilly, Charles. 1991. "Transplanted Networks" In Immigration Reconsidered: History, Sociology and Politics, edited by VirginiaYans-McLaughlin, 79-95. New York: Oxford University Press.

Troc, Gabriel. 2012. "Patterns of Migration and Economic Development in Southern Danube Micro-region." Studia Europaea 57(3): 85-116.

Vertovec, Steven. 2000. "Religion and Diaspora." Paper presented at the conference on New Landscapes of Religion in the West. Oxford, School of Geography and the Environment, University of Oxford, September 27. 